\title{
Beckett's Path of Least Resistance: Attention, Distraction, Drift
}

\author{
Yael Levin \\ The Hebrew University of Jerusalem, Israel
}

Copyright (c) 2019 by Yael Levin. This text may be archived and redistributed both in electronic form and in hard copy, provided that the author and journal are properly cited and no fee is charged for access.

\begin{abstract}
This essay utilizes Beckett's fictional and critical explorations of attention, distraction and drift to reflect on the ways in which, stripped of the conventions of cultural production, walking, thinking and artistic endeavor might be reimagined outside the normative scripts of biopolitics. Centralized and teleological forms give way to rhizomatic instantiations of the same in a process pertaining to all three registers at once (walking, thinking and writing). The result is the formation of a gesture that though suggestive of resistance cannot be viewed as such, in so far as it eschews negation. The paper traces a movement from the dialectical oscillation of attention and distraction in Proust to Beckett's fashioning of an alternative that finds expression not only in the abstractions of thought and language but also in embodied experience. This alternative will be termed "drift," a label denoting neither principle nor concept, but a mode of being that anticipates our attempts to think the human in the sensorydigital present. Beckett's experiments allow us to reconsider forms of knowledge, understanding and conditioning. No less significant is his lesson on how we might do so without becoming embroiled in the dialectics of resistance and compliance.
\end{abstract}

Key Words. Beckett, Biopolitics, Attention, Distraction, Drift, Posthuman, The Subject.

Resumen. El presente artículo es una reflexión sobre el uso ficcional y crítico que Beckett hace de los conceptos de atención, distracción y deriva con el fin de determinar los modos mediante los cuales acciones como el andar, el pensar o el trabajo artístico son reimaginados al separarse de las convenciones de la producción cultural y de los patrones normativos de la biopolítica. Las formas centralizadas y teleológicas dan paso a ejemplos rizomáticos de los mismos mediante un proceso que implica a los tres registros (andar, pensar y escribir) de manera simultánea. El resultado es la formación de un gesto que, aunque sugiere una idea de resistencia, no puede verse como tal, ya que rehúye de la negación. Este artículo traza el paso de una oscilación dialéctica de la atención y la distracción en Proust a la creación, por parte de Beckett, de una alternativa encarnada tanto en las abstracciones del pensamiento y el lenguaje como en la experiencia corpórea. A esta alternativa se la denominará deriva, una etiqueta que no denota principio o concepto, sino más bien un modo de pensar que se adelanta 
a nuestros intentos de aprehender lo humano en el presente sensorio-digital. Los experimentos de Beckett nos permiten reconsiderar modos de conocimiento, entendimiento y acondicionamiento. También es importante su lección sobre cómo llevar a cabo lo anterior sin caer en la trampa de la dialéctica de la resistencia y la conformidad.

Palabras clave. Samuel Beckett, biopolítica, atención, distracción, deriva, posthumano, el sujeto.

This essay utilizes Beckett's fictional and critical explorations of attention, distraction and drift to reflect on the ways in which, stripped of the conventions of cultural production, walking, thinking and artistic endeavor might be reimagined outside the normative scripts of biopolitics. Centralized and teleological forms give way to rhizomatic instantiations of the same in a process pertaining to all three registers at once (walking, thinking and writing). The result is the formation of a gesture that though suggestive of resistance cannot be viewed as such, in so far as it eschews negation. The paper traces a movement from the dialectical oscillation of attention and distraction in Proust to Beckett's fashioning of an alternative that finds expression not only in the abstractions of thought and language but also in embodied experience. This alternative will be termed "drift," a label denoting neither principle nor concept, but a mode of being that anticipates our attempts to think the human in the sensory-digital present. Beckett's experiments allow us to reconsider forms of knowledge, understanding and conditioning. No less significant is his lesson on how we might do so without becoming embroiled in the dialectics of resistance and compliance.

Beckett unpacks Marcel Proust's aesthetics by tracing a movement from distraction to attention. "The pernicious devotion of habit", he explains, "paralyses our attention, drugs those handmaidens of perception whose co-operation is not absolutely essential" (Proust 9). Serving as a mouthpiece for Schopenhauerian aesthetics, Beckett promotes an art whose function is to facilitate concentration. It distills our perception through the staging of defamiliarizing moments that allow for an appreciation of reality in its beauty and mystery:

When the object is perceived as particular and unique and not merely the member of a family, when it appears independent of any general notion and detached from the sanity of a cause, isolated and inexplicable in the light of ignorance, then and then only may it be a source of enchantment. Unfortunately Habit has laid its veto on this form of perception, its action being precisely to hide the essence - the Idea - of the object in the haze of conception - preconception. (Proust 11)

In this early critical analysis of Proust's In Search of Lost Time Beckett subscribes to binary opposition in a way that will later become insupportable. Perception, sight, concentration and insight are the purpose of artistic labor, the enchantments it produces in its audience. Distraction serves as its noxious other, a necessary evil amidst the horrors of the real. To see beauty is to suffer it. Beckett describes the movement between modes of experience as working through the conceit of a swinging pendulum. Where Proust excels is in creating those in-between moments, when old habits die and new ones have yet to take their place: "between this death and that birth, reality, intolerable, absorbed feverishly by his consciousness at the extreme limit of its intensity, by his total consciousness organised to avert the disaster, to create the new habit that will empty the mystery of its threat - and also of its beauty" (11). Proust's art traces an oscillation from distraction to attention, from obliviousness to 
revelation. Its full force is encountered in that "extreme limit" of intensity, an experience of the totality of consciousness.

To reread the passage with Louis Althusser's "Ideology and Ideological State Apparatuses" is to transpose the same dialectic from within the realm of aesthetics to one of power. Habit is conscripted here to form the "material existence of an ideological apparatus" (114, italics in the original). It is found in the rituals of cultural life that we repeat daily: "a small mass in a small church, a funeral, a minor match at a sports' club, a school day, a political party meeting, etc." (114). The dialectic may thus be rethought as the oscillation between the material internalization and enactment of state ideology (through interpellation) and the achievement of an awareness of its manipulations. Such awareness is facilitated by the formation of a critical distance from those same practices and the ideology that underpins them. Much like the defamiliarizing moment of aesthetic appreciation, we become alert to ideological manipulation only through a distillation of focus, an intense exercise in concentration. It is in this manner that we transcend beyond the recognitions already inherent in the rituals of everyday life. We may have "consciousness" of our incessant (eternal) practice of ideological recognition - its consciousness, i.e. its recognition - but in no sense does it give us the (scientific) knowledge of the mechanism of this recognition". It is this latter "knowledge that we have to reach ... and from within ideology we have to outline a discourse which tried to break with ideology, in order to dare to be the beginning of a scientific (i.e. subject-less) discourse on ideology" (117). Defamiliarization emerges as a liberating force; ritual breaks down and the subject no longer follows the scripts of the Ideological State Apparatus. These moments of intense concentration allow, if only fleetingly, for political and aesthetic freedom.

This doubly significant dialectical trajectory is leveled out in Beckett's later art. A life punctuated by moments of attention is no longer seen as a source of empowerment but as punishment. Many examples of such leveling can be brought in evidence. In "An Abandoned Work", a work written nearly thirty years after the publication of Proust, we find the following:

But let us get on and leave these old scenes and come to these, and my reward. Then it will not be as now, day after day, out, in, round, back, in, like leaves turning, or torn out and thrown crumpled away, but a long unbroken time without before or after, light or dark, from or towards or at, the old half knowledge of when and where gone, and of what, but kinds of things still, all at once, all going, until nothing, there was never anything, never can be, life and death all nothing, that kind of thing, only a voice dreaming and droning on all around, that is something, the voice that once was in your mouth. (163)

The reward described here is not the freedom afforded by a release from habit, not an extreme intensity of concentration, but rather monotony - a droning, familiar voice with no peaks, no starts, no distinguishing temporal or spatial markers. What the narrator describes is a release from "these old scenes", the narrative signposts of a measured life, of a sequence of regulated and familiar life events. Whether we read this alternative state as "the final extinguishment of death or an intra-uterine calm" (Salisbury, Laughing Matters 163), the description is suggestive of a departure from prescribed forms of narrative, and indeed, of life itself.

The transition from the peaks and valleys of Proust to the monotone envisioned in the later work does not necessarily suggest a long-cogitated artistic plan or the signs of a maturing vision. The early work is already shadowed by a double that features a conceit similar to that presented in "From an Abandoned Work". Presented to the Modern Language Society of Trinity College in November 1930 (the very year in which Proust was published), 
Le Concentrisme describes a flat existence akin to that found in the late work. Ruby Cohn has noted that, "academic spoof though it is, the biography and beliefs of Chas obliquely predict the later Beckett" (22). Life flows without the conventional temporal signposts associated with narrative; it no longer conforms to the edicts of spatialized time: a sequence of events on a linear trajectory with a clearly demarcated start and end point. Althusser explains that birth becomes culturally coopted in gesturing to the fact that the child is "always-already a subject, appointed as a subject in and by the specific familial ideological configuration in which it is 'expected' once it has been conceived" (119). Beckett undoes the ideological apparatus by ridding these cultural signifiers of their signifieds. Birth and death are no longer to be understood as events marking the inauguration and conclusion of a life:

Cette vie ... est une de ces vies horizontales, sans sommet, toute en longueur, un phénomène de mouvement, sans possibilité d'accélération ni de ralentissement, déclenché, sans être inauguré, par l'accident d'une naissance, terminé, sans être conclu, par l'accident d'une mort. $(38)^{2}$

Such a life replaces the culturally sanctioned punctuations of life with the immersive experience of duration. By excluding the conventions associated with social ritual, the state is effectively stripped of its power over the individual. ${ }^{3}$ The cancellation of the significance of birth similarly strips the reader of his ability to master the text through the application of a biographical reading. That Beckett shares du Chas's birth date is tantalizingly suggestive of a commonality between the two at the same time that it is voided of significance. Birth and death are no longer definitive of subjectivity; we cannot utilize their instantiations to draw conclusions about the subject who suffers them.

The passage is of particular relevance to Althusser's analysis of the material form of ideology in that the flatness described is associated with life; this is not a fantasy of death. In such a life, the dictates of the social contract are persistently denied. The material articulations of ideology are thereby cancelled out:

De vie sociale, pas une trace. En lisant son Journal on a l'impression que pour cet homme et fatalement et en dehors de toute action d'orgueil ou de mépris, la vie sociale, la convention sociale, toute l'ennuyeuse et prudente stylisation des afflictions humaines, amour, amitié, gloire et le reste, que tout cela n'était qu'une dimension, ou l'attribut d'une dimension, inévitable, comme la friction, une condition de son adhésion à la surface de la terre. De sorte que du Chas avait une vie sociale comme vous avez une vie centripète, à savoir, inconsciemment et indifféremment, ce qui équivaut à dire qu'il en était exempt, car l'indifférence et l'inconscience ne cadrent guère avec la tradition sacrosainte de la cave et la peur et l'ignorance et la solidarité crispée sous le tonnerre. $(38)^{4}$

The rejection of a social life is attended by the disappearance of the cultural rituals that work to control the subject. In reversing the lessons employed in Proust, Beckett here suggests that freedom is found not in the distillation of attention but in a state of stupor. It is not by engaging resistance but rather through indifference - "en dehors de toute action d'orgueil ou de mépris" - that one might escape the snares of an oppressive solidarity, those cultural stylizations that effectively allow for ideology to be policed and maintained.

Aesthetics follows suit. Beckett travesties academic scholarship in Le Concentrisme to suggest that if concentration is the apex of artistic endeavor, it might also sound the death knell for academic scholarship. Jean du Chas assaults the narrator much as defamiliarization assaults the reader in Proust's writing: 'Il s'est cramponné à moi dans un sombre bistrot où, à 
cette époque, j'avais l'excellente habitude d'aller me soûler deux fois par semaine" (35). ${ }^{5}$ The frequenter of the bar leads a life of habit, repetition, a drunken haze. The writer disrupts his routine; he makes demands on his attention:

\begin{abstract}
'Au nom de tout ce qui vous est précieux' me dit-il, 'venez à cette adresse demain vers midi, présentez cette carte, dites que vous êtes le Toulousain, dites que...' Je lui coupai la parole. 'Monsieur' lui dis-je, ‘je n'en ferai rien et je ne viendrai pas. Je ne vous connais pas, vous m'avez insulté, vous. ...' 'Mais si' insista-t-il, Presque avec impatience, 'mais si, vous viendrez.' $(35-36)^{6}$
\end{abstract}

In a veritable enactment of defamiliarization, Du Chas demands the academic give up the familiarity of his nighttime habit for an encounter with the unknown in the light of day. Similarly, the parcel the academic will inherit from the writer will itself be a metonymical extension of the attention the writer demands: "Dans le paquet il n'y avait que les cahiers qui vous ont si fort intrigué" (36)..$^{7}$ The undercutting of the value of concentration in critical practice is shadowed by the suggestion that artistic production is itself prey to the errors of focus. As Cohn goes on to note: 'Jean du Chas, who experiences 'crises de negation,' is an individual who cannot explain himself, but who nevertheless creates an art that is 'parfaitement intelligible et parfaitement inexplicable' - Beckett's translation into French of his own phrase in praise of Proust" (22). The collapsing of the respective artistic endeavors of du Chas and Proust may be integral to the hoax of Le Concentrisme and should not be taken at face value. A closer examination of some of the instantiations of the theme in Beckett's writing would nevertheless show that, joking aside, the attention/distraction dialectic explored in Proust is associated elsewhere with the oppressions that attend the process of becoming a subject. To court freedom is to void this dialectic and attempt a different mode of being.

\title{
Literature in the Service of the Ideological State Apparatus: The Case of Attention/Distraction
}

In Distraction: Problems of Attention in Eighteenth-Century Literature, Natalie M. Phillips describes a shift away from the tradition of "religious meditation" wherein "the virtues of paying attention to one thing (and only one thing)" are emphasized and distraction is seen as a sin of "the mind literally wandering from the way of God" (4). In support of her argument that distraction is reclaimed as a dynamic, all-encompassing and creative method of engagement, she notes Denis Diderot's 1754 claim that it "arises from an excellent quality of the understanding, which allows the ideas to strike against, or reawaken one another. It is the opposite of the stupor of attention, which merely rests on, or recycles, the same idea" (5). The shift may describe the vindication of a once morally suspect term, but such a reconfiguration of the term limits even further a subject's freedom to exceed the dictates of a culturallysanctioned life. Whether attentive or distracted, the individual is forced onto a path of effective citizenship: "rather than signifying a truant mind off path, adrift, or torn, distraction's multiplicity was reimagined as a spur to creativity" (Phillips 5). The circularity of these terms is succinctly articulated in Jonathan Crary's Suspensions of Perception where he suggests that "Attention was not part of a particular regime of power but rather part of a space in which new conditions of subjectivity were articulated, and thus a space in which effects of power operated and circulated" (23).

Mid to late nineteenth-century writing readily attests to the policing of both attention and distraction in the name of a positive contribution to the principles of economic liberalism upon which the healthy state stands. In Charles Dickens's Bleak House, Esther Summerson regrets her good friend Richard is not educated in "habits of application and concentration", 
habits that would have allowed him to master medicine or law. Richard's distractions finally give way to a fixed idea in his pursuit of the Jarndyce and Jarndyce suit. But obsession is attention taken to an unproductive extreme, a source of weakness rather than efficacy. Wasting away in the courts of law and at home, Richard becomes a financial and psychological burden to his wife.

In keeping with this example, Max Nordau's Degeneration shows distraction and attention to be two complementary expressions of the same social ills that are definitive of the devolutionary processes he diagnoses. Recalling the binary at work in du Chas's imposition on the drunken academic, Nordau likens "the consciousness of a healthy, strong-minded, and consequently attentive man" to "the full light of day", where "the eye sees all objects distinctly, in which all outlines are sharp, and wherein no indefinite shadows are floating". Attention "presupposes strength of will, and this, again, is the property only of a normally constituted and unexhausted brain". In contradistinction, "all weakened persons are incapable of attention"; their brain activity lacks "aim or purpose" (62). The imbecile, the mystic and the degenerate artist alike lack the proper function of attention; their hold on reality is too precarious and confused to make for a healthy contribution to public life. Instead, such members of society endanger the social fabric of the state by propagating and spreading their superstition and mysticism: "under the influence of an obsession, a degenerate mind promulgates some doctrine or other .... He does this with vehement penetrating eloquence, with eagerness and fiery heedlessness" $(37){ }^{8}$

\section{The Perils of the Dialectic}

That attention and distraction are finally both coopted in service of the principles of production plays into the overarching hopelessness associated with dialectics at the outset of The Unnamable. To paraphrase, if "affirmations and negations " are "invalidated as uttered", "there must be other shifts. Otherwise it would be quite hopeless" (285). The same swings of the pendulum that are key to the aesthetic principle in Proust here reemerge as a tireless and pointless series of distillations and dilutions. Their sole purpose is to keep the Unnamable trapped in his subjugation. As he comments in passing, "rest is one of their words and think another" (328). The protagonist's maneuvers between attention and distraction, compliance and resistance, gaining ground and retreating, come at a cost; the mental anguish of the incessant back and forth results in a radical physical deterioration: first the loss of a leg, then an arm, until finally "only the trunk remains" (321). What the Unnamable lacks is an alternative, that "other shift" mentioned at the start. Without it he has no choice but to continue shuttling back and forth:

The only problem for me was how to continue, since I could not do otherwise, to the best of my declining powers, in the motion which had been imparted to me. This obligation, and the quasi-impossibility of fulfilling it, engrossed me in a purely mechanical way, excluding notably the free play of the intelligence and sensibility, so that my situation rather resembled that of an old broken-down cartor bat-horse unable to receive the least information either from its instinct or from its observation as to whether it is moving towards the stable or away from it, and not greatly caring either way. (314)

Such moments of insight nevertheless lead back to the confinement born of the need to "concentrate more often" (335) and the failure to do so, as it is so difficult to "focus one's attention" "where one's true interest lies" (302). 
Phillip's suggestion that distraction is itself reclaimed in the service of good citizenship may also allow us to reconsider the motif not as the Unnamable's rebellion against power but as a reinforcement of his subjugation. To make his voice his "in a moment of confusion" (342) may well be a mirror expression of the same principle underlying the call to attention, as both function to resuscitate the liberal-humanist subject, a subject created to serve the state and the liberal economy on which it relies. To be a subject is to be known, monitored, placed and circumscribed. As he notes: "my thoughts are elsewhere. I am therefore forgiven. So long as one's thoughts are somewhere everything is permitted" (316317). The comment offers a powerful illustration of the way distraction might be complicit in the policing of state power. Attention and distraction both situate the subject - the first here, the second elsewhere - so that he can be controlled. ${ }^{9}$ In keeping with this principle, such control is often articulated in spatial metaphors. The Unnamable is "walled around with their vociferations" (319); he is "on the island" and he's "never left" (320) and then "stuck like a sheaf of flowers in a deep jar, its neck flush with my mouth, on the side of a quiet street near the shambles" (321). Silent, immobile, dismembered, he is neither able to arouse dissent through the use of rhetoric, nor offer offense by begging for a handout. That biopolitics is used to ensure that the Unnamable is innocuous is perhaps less remarkable than the manner in which it does the same to render him culturally productive. Though he is symbolically reduced to a form of bare life in a jar, he is still working for the promotion of good public health. As he notes: "those who can bring themselves" to look at him "have immediately their minds made easy. For my face reflects nothing but the satisfaction of one savouring a wellearned rest". The Unnamable's attempted transgressions against power fall flat. "Though not exactly in order I am tolerated by the police" (321).

\section{“Other Shifts": Drift}

"The thing to avoid", the Unnamable realizes, "is the spirit of the system" (286). The key to such avoidance may well be in a diffusion of the I as imagined in the following passage "From an Abandoned Work":

I too shall cease and be as when I was not yet, only all over instead of in store, that makes me happy, often now my murmur falters and dies and I weep for happiness as I go along and for love of this old earth that has carried me so long and whose uncomplainingness will soon be mine. Just under the surface I shall be, all together at first, then separate and drift, through all the earth and perhaps in the end through a cliff in to the sea, something of me. (160)

The dissemination of the subject is cast in a set of images that evoke death and decomposition. But if we reread this death as that of the liberal-humanist subject the passage allows us to reimagine the future of the anthropocene without its attending dictates that human life be circumscribed, whole, autonomous and separate, an existence governed by reason and a conscious and deliberate will. Such a reimagined subjectivity will have to be thought in life rather than in death; the human "in store" and the human "all over" will have to be thought together rather than separately. In "The Genesis of the Individual" Gilbert Simondon offers a conceptualization of the subject that allows us to think beyond its Enlightenment antecedent and the narratives in which such a being is circumscribed:

The conception of being that I put forward, then, is the following: a being does not possess a unity in its identity, which is that of the stable state within which no transformation is possible; rather, a being has a transductive unity, that is, it can pass 
out of phase with itself, it can - in any area - break its own bounds in relation to its center. What one assumes to be a relation or a duality of principles is in fact the unfolding of the being, which is more than a unity and more than an identity; becoming is a dimension of the being, not something that happens to it following a succession of events that affect a being already and originally given and substantial. (311)

The passage offers two insights that are pertinent to the discussion here. First, Simondon's human subject is decentered. Such decentering is suggestive not of confusion but of a complex coincidence of interdependent and unstratified processes of renewal and change. The second insight touches on the subject's relation to time. To view the process of individuation as an ongoing rather than a finished process is to understand time differently - not as that which the individual suffers, but as the ongoing and unpunctuated backdrop against which the individual continues to become.

If being spatially located is the key to falling into the system's grip, the "other shift" may well lie in never being still: "The essential is never to arrive anywhere, never to be anywhere (The Unnamable 332); "I am he who will never be caught, never delivered" (332333). This last sentence stages an evasion of the situatedness that allows the voices to wall the Unnamable in; it also traces a transition from the subject to the object position, a movement that is suggestive of the decentering of experience and a becoming one with a world that is conventionally held separate from the cogito. The result is a form of spatial obfuscation where the subject is no longer complicit with the predictable and knowable rituals and behaviors that allow for state control; it likewise cancels out the notion of self-monitoring as the new subject is not governed by a centralized agency but is a conglomerate of independent networks of evolution and change.

David T. Mitchell and Sharon L. Snyder argue that "what is often lost in relations of neoliberal normalcy are ways in which disabled people's openly interdependent lives and crip/queer forms of embodiment provide alternative maps for living together in the deterritorialized, yet highly regulated spaces of biopolitics" (3). In presenting new modes of thinking, writing and walking, Beckett allows us to imagine what Mitchell and Snyder refer to as "nonproductive bodies within late capitalism" (27). Where Mitchell and Snyder employ their investigation as a method to "mutate the recognition of disability as a pragmatic category for engaging enactments of nationalism and normative expectations of citizenship" (27), my aim is to offer a way to think anew the place of any individual in a digital world that is not only constantly watching and monitoring us, but is also forcing our complicity by making our own online avatars conform to the regulated and universalizing algorithms that leave little space for irregularity and unpredictability. Such methods of manipulating our attention, moreover, do not necessarily adhere to a distinction between the disabled and the normate. Crary argues that "television and the personal computer, even as they are not converging toward a single machinic functioning, are antinomadic procedures that fix and striate. They are methods for the management of attention that use partitioning and sedentarization, rendering bodies controllable and useful simultaneously, even as they simulate the illusion of choices and "interactivity" (75). The reach of media and its power to control the individual may well be in effect over a broad spectrum of cognitive and physical ability, one that explodes the categorical divide between the disabled and the normate. To make such a suggestion is to depart from Mitchell's and Snyder's project not only by looking beyond disability as a pragmatic category for the reconfiguration of nationalism and normative expectations of citizenship but also by using the debate to reflect on the more wide-ranging future of human subjectivity. ${ }^{10}$ That is not to say that the paper calls for a distillation of Beckett's writing into the formation of a new, overarching conceptualization of the human. 
To follow Simondon's suggestion that we are each multiple and in a constant state of evolution contiguous with our environment, is to eschew universally applicable categories: to court difference rather than similarity. ${ }^{11}$

If attention and distraction emerge as the material expressions of a system that seeks to police irregularities back into categories that the state uses to regulate and control its subjects, Jean-Francois Lyotard's term "drift" might be seen as that "other shift" that the Unnamable seeks. Further reinforcing the suspicion that distraction is the product of the very principle it attempts to undermine, Lyotard argues that any resistance orchestrated within dialectics is no resistance at all: "Negating. This activity is deeply rational, deeply consistent with the system. Deeply reformist: the critic remains in the sphere of the criticized, he belongs to it, he goes beyond one term of the position but doesn't alter the position of terms" (13).

The alternative that Lyotard describes in Driftworks signals a liberation from the normalizing scripts of biopolitics. Drift is associated with "an aimless voyage, a collection of fragments impossible to unify ... in accordance with the diversity of the times and sceneries wafted through." It is "the Odyssey displaced - not at all Ulysses' polymorphy collected and gathered, totalized in a return home, to the self, which will be the model of Hegelian dialectics and of bourgeois socialist thought and praxis in their entirety. Rather the intense stationary drift wherein the fragments clash in Joyce's Ulysses" (10). What follows is an attempt to locate such moments of drift in Beckett's work and to consider how the decentered subjectivity with which they are associated is neither complicit with the regulating power of the Ideological State Apparatus nor an extension of an aesthetics of distraction as associated with "Georg Simmel, Walter Benjamin, Sigfried Kracauer, Theodor Adorno, and others" who, Crary notes, "presumed that a distracted perception was central to any account of subjectivity within modernity" (48).

\section{Walking}

Nordau draws an explicit connection between the attention of the mind and the healthy functioning of the body:

As with defective attention there ensues no intelligent thought, so with faulty coordination there can be no appropriate movement. Palsy is equivalent to idiocy, St. Vitus's dance to obsessions and fixed ideas. The attempts at witticisms of the weakminded are like beating the air with a sword; the notions and judgments of sound brains are like the careful thrust and parry of skillful fencing. Mysticism finds its reflected image in the aimless and powerless, often hardly discernible, movement of senile and paralytic trembling; and ecstasy is, for a brain-centre, the same state as a prolonged and violent tonic contraction for a muscle or group of muscles. (70)

Beckett's method of describing his protagonist's gait in Watt offers an illustration of what Nordau would diagnose as degenerate movement. Watt's way of walking is to turn "his bust as far as possible towards the north and at the same time to fling out his right leg as far as possible towards the south, and then to turn his bust as far as possible towards the south and at the same time to fling out his left leg as far as possible towards the north, and then again to turn his bust as far as possible towards the north and to fling out his right leg as far as possible towards the south" (28). Lady McCann's scans the categorical repositories of her memory in attempt to comprehend Watt's "funambulistic stagger" (29). And though she succeeds in accounting for the uncouth movement of the legs (which might be relegated to piles, the clap or wind - as the old story of her girlhood days confirms) she remains "puzzled" (29) by the unexplained movement of the head from side to side. Her inability to diagnose Watt's walk is 
an insupportable offence. That she cannot categorize or label his walk means that she must take measures to correct it. She does so by hurling a stone at him. The act is "faithful to the spirit of her cavalier ascendants" (30) and guided (it is supposed) by God. It is thus with the full-force of her righteous duty to police Watt back into normative behaviour that she disabuses him of the notion that he can share the sidewalk with the likes of her.

The scene demonstrates the way in which any transgression of the prescriptions of those social rituals (in this case - walking in the street) are constantly supervised, monitored and corrected in accordance with the Ideological State Apparatus. The state need not intervene as it is its very citizens who, guided by the dictates of decorum, habit and religious faith, can be relied on to serve as the executive extensions of its power.

Watt's method of advancing is also helpful in considering how we might apply the idea of drift to a self that is not yet "all over"; he drifts in life. At the start it appears that his movement stems from the willed effort of a centralized agency, suggesting the conceit is not applicable here. It is Watt who turns and flings his bust and legs to achieve the desired effect. And yet, as the description unfolds the different parts of the body assume independence from the subject they initially appear to serve. As Ulrika Maude notes, "Beckett foregrounds the involuntary nature of Watt's movements by giving 'his bust,' 'his right leg' and 'his left leg' a curiously autonomous status in the syntax, in order to underscore their localised behaviour" ("A Stirring" 156-157). ${ }^{12}$ Note the nouns assuming a subject position in the following lines: "The knees, on these occasions, did not bend. They could have, but they did not. No knees could better bend than Watt's, when they chose ... But when out walking they did not bend, for some obscure reason" (29). Similarly his feet appear to have an autonomous set of desires and emotional responses, falling as they do, "heel and sole together ... with manifest repugnancy". Finally, his arms follow the same pattern. It is they and not Watt who are "content to dangle, in perfect equipendency" (29). The agency of his limbs is suggestive of such a departure from our conceptualization of the human that it upsets the very conventions of language (a language that itself reflects and ensures the survival of such a conceptualization). Maude connects this scene to Derek Attridge's analysis of the way in which "the English language allows very little independence to the organs of the body: most verbs of conscious behaviour require a grammatical subject implying an undivided, masterful, efficient self of which the organ is the mere slave or satellite" (160). Watt's gait debunks the separation of object and subject on which syntax - and the Cartesian cogito that it accommodates - rely. The liberal-humanist subject and the productive efficiency which he propagates are both cancelled out. What emerges instead is a complex unit that is composed of multiple interconnected systems, each sporting its own unique dynamic and autonomous sense. Watt's walk cannot be corrected; it is neither attentive nor distracted (two modes that are suggestive of an efficient or inefficient centralized agency) and therefore cannot be remedied by balancing it out through the evocation of its binary opposite. ${ }^{13}$ Such a method of walking offends public decency by being entirely unknown, unpredictable and inefficient. In Lyotard's words, it is a form of drift, an example of

fragments placed next to each other (the category of neben!) for an aimless voyage, a collection of fragments impossible to unify .... Not at all a dislocated body, since there has never been anything but pieces of the body and there will never be a body, this wandering collection being the very affirmation of the non-body. The plural, the collection of singularities, are precisely what power, capital, the law of value, personal identity, the ID card, responsibility, the family and the hospital are bent on repressing. (10) 


\section{Writing, Thinking}

In the preface to Texts for Nothing and Other Shorter Prose, 1950-1976, Mark Nixon describes a pattern that becomes definitive of Beckett's late method of composition, one that reads as the creative expression of drift. The decentralization of the subject and the cancelling out of the principle of efficiency exemplified in the passage from Watt are here brought to bear on the author's writing practice. Nixon notes that Beckett "is no longer a writer who starts and completes a work, but one who across a wide range of texts realizes that there is no possibility of completion. As the surviving manuscripts from this period show, Beckett would start one text, lay it aside to start another, and then return to the original, or amalgamate the two, or abandon both" (vii).

Dirk Van Hulle views this new method of writing together with the themes explored in the late works as an indication that "Beckett seems to have anticipated some of the recent developments in cognitive science", notably the postcognitive approach where the mind is not separate from the world it perceives but is contiguous with it. Such a view not only speaks to a new materialist conception of our relation to the world but also to the decentering of the mind's activity so that that "all varieties of perception and all varieties of mental activity are accomplished by 'parallel, multitrack processes of interpretation and elaboration of sensory input"' (282). Posited as an alternative to the Cartesian cogito, such a decentered subject and its continuity with the material world dovetails with the exploration of drift offered here. It traces the emergence of a new conceptualization of the human and his relation to the world that upsets "presumptions about agency and causation implicit in prevailing paradigms [that have] structured our modern sense of the domains and dimension of the ethical and the political as such" (Diana Coole and Samantha Frost 6) and thereby allows us to read Beckett's work and his method as the attempt to question some of the ways in which biopolitics have regulated and limited our experience. It also allows us to think of ways to undo or improve such scripts in the future.

"Critique" Lyotard argues, "must be drifted out of. Better still: Drifting is in itself the end of all critique" (14). This paper drifts in and out of Beckett's works and emerging critical theory in order to imagine, neither too attentively nor distractedly, how we might reframe our life in the digital-sensory present. Our digital life allows us to be simultaneously co-present across a number of digital, physical and cognitive maps. The postcognitive and sensory turns in criticism, meanwhile, allow us to consider modes of knowledge and awareness that exceed their localization in the rational mind. But where Beckett's characters - and perhaps Beckett as writer - are liberated from the Ideological State Apparatuses that dictate how one should be and write, we may well find ourselves once again in the clutches of biopolitical measures of regulation through the digitization of biological information and control. In an article on biohacking in Trends in Biotechnology Ali K. Yetisen notes that "The biohacking community actively discusses mass surveillance implications of implantable devices that may be used to control citizens". Yetisen then cites the recent example of Ross Campton of Ohio "who was convicted of arson and insurance fraud after law enforcement used heart function data from his pacemaker as supporting evidence to prosecute him" ("Biohacking" 744). ${ }^{14}$ If biopolitical power can now be enforced on a single limb or organ, the fragmentation of our virtual and physical being may no longer be an effective measure against state intervention. We can find consolation in the fact that "there must be other shifts. Otherwise it would be quite hopeless" (The Unnamable 285). Should we require new paths in order to drift a little further, we will surely find them in Beckett. 


\section{Notes}

${ }^{1}$ Habit is a philosophically complex term and can potentially and rather performatively distract from the paper's focus on attention, distraction and the undoing of the dialectic that binds them. The passing references to the term here are significant only insofar as they are relevant for the testing of culturally sanctioned modes of attention. To briefly reference more sustained engagements with habit, Ulrika Maude utilizes Félix Ravaisson's definition of habit as a method to unpack its shifting significance in Beckett's work. She concludes that "Although Beckett perhaps begins his publishing life with a Bergsonian take on habit as "the ballast that chains the dog to its vomit", something that impedes knowledge and distracts us from experience, .... in Beckett's late work, habit seems to constitute a tenuous, fraught, and primitive ontology, which is the most, perhaps, that we can hope for" ("The Laws of Habit" 820). Laura Salisbury's Samuel Beckett: Laughing Matters, Comic Timing turns to "the semi-automatic, the half-intentional", the "habitual affects that tread the threshold of what can securely be brought into the conscious awareness" (217). My paper participates in the attempt to trace an emerging ontology in Beckett's work, but does so by following the instantiations of habit only insofar as they are socially and culturally determined and regulated. Work on this paper was supported by the Israel Science Foundation grant "Pioneering the Slow" 468/17.

2 "This life ... is one of these horizontal lives, without a peak, all outstretched, a phenomenon of movement, without possibility of speeding up or slowing down, launched, without inauguration, by the accident of birth, ceased, without conclusion, by the accident of death." The translation used throughout is Michael Zeleny's. https://larvatus.livejournal.com/68681.html Accessed 24th April 2019. My thanks to Paul Fagan for the reference.

${ }^{3}$ It is possible to turn to Pierre Bourdieu for a more complex sketching of the way in which habit (or habitus) marks an interrelation between self and others, one that is perhaps more cognizant of the shifting habits of the individual and society and the way in which these are dynamically interrelated. Bourdieu states that "Personal" style, the particular stamp marking all the products of the same habitus, whether practices or works, is never more than a deviation in relation to the style of a period or class" (86). Such a deviation is suggestive of yet another dialectic from which it is difficult to escape - in Bourdieu's terms, "the dialectic of the internalization of externality and the externalization of internality" (72). Here, too, Beckett's method of drifting may be brought as a productive alternative.

${ }^{4}$ Of a social life, not a trace. By reading his Diary one gets the impression that for this man, fatally and beyond any action of pride or contempt, social life, social convention, all tedious and careful stylization of human afflictions - love, friendship, glory and the rest - that all that was only one dimension, or the attribute of a dimension, inevitable, like friction, a condition of his adhesion to the surface of the earth. So that Chas had a social life as you have a centripetal life, namely, unconsciously and indifferently, which is the same as saying that he was free of it, because the indifference and unconsciousness hardly tally with the sacrosanct tradition of the cave and the fear and ignorance and the solidarity contracted under the thunder.

${ }^{5} \mathrm{He}$ latched himself onto me in a dark bar where, at that time, I had the excellent habit of going twice a week to get myself drunk.

6 "In the name of all that is dear to you," he begged me, "come to this address tomorrow about midday, present this card, say that...." I cut him off. "Monsieur," I said to him, "I will not do anything of the sort and I will not come. I do not know you, you have insulted me, you...." "Not at all," he insisted, almost impatiently, "not at all, you will come."

7 "The package contained only the notebooks that so powerfully captivated you."

${ }^{8}$ My thanks to Seán Kennedy for pointing out this important intertext. Crary reads Nordau's cultural manifesto with the work of nineteenth-century figures such as psychologist Théodule Ribot to demonstrate the scientific underpinnings of Degeneration. In The Psychology of Attention (1889), Ribot writes that, "untended and unrestrained by attention, the brain activity of the degenerate and hysterical is capricious and without aim or purpose" (qtd. in Crary 16).

9 In this I am departing from Paul North's use of the term as a performative escape. In The Problem of Distraction he suggests that "what Kafka, Heidegger, and Benjamin - taken together - intimate is the following. Where philosophy, criticism, and art theory are traditionally concerned with principles for the formation of things, distraction is concerned with their deformation, disintegration, and ceasing to be. It posits a tendency toward not-thinking and a release from being" (15).

${ }^{10}$ Mitchell and Snyder object to this critical slippage on the grounds that it entails the turn to "a problematic "we' that discounts those with disabilities by suggesting all of us occupy failed embodiments in some way without an ability to attend to crip/queer materiality's nuances of experience" (30). Though the analysis conducted here is contiguous with the goals of disability theory it significantly departs from them in two ways. First: it seeks to follow Beckett's writing to a thinking of the human that is not circumscribed within the confines of the 
particularities of a single category of subjectivity; Beckett's writing is applicable to the disabled and normative subject both. Secondly, it seeks to question the inevitable slippage into categorical thinking that occurs when we think of the human. The aim here is not to universalize so much as to explore the manner in which we might think outside the generalizations of conceptual logic.

${ }^{11}$ Catherine Malabou's "One Life Only" provides biological terms that may be used to unpack Simondon's analysis. She describes epigenetics as an alternative model for the understanding of life processes to preformationism. Where the latter assume "that the living organism is wholly constituted in advance, in miniature, in the seed" (434), epigenetics allow us to gauge how "modifications of the master of the genes depend not only on internal and structural factors ... but also on environmental factors" (435).

12 The scene has generated many critical readings. Where Maude emphasizes the way in which Watt's gait is demonstrative of a lack of a coordinating agency, Steven Connor sees it as an "ongoing, chaotic compromise between the dimensions of up and down, left and right. It is only Watt's clownish imbalance that keeps him on the move" ("Shifting Ground"). Such a reading highlights a certain agentic coherence - the imbalance and the compromise are both attributed to Watt as agent.

${ }^{13}$ In this, the passage significantly departs from other instantiations of the same dynamic. In "The Expelled" (1946) the protagonist is regulated and self-regulated within the dialectical divide (and here my reading departs from Maude's in so far as her tracing of the scene is offered as a more striking example of the dynamic observed in Watt). The Expelled notes: "A man must walk without paying attention to what he's doing, as he sighs, and when I walked without paying attention to what I was doing I walked in the way I have just described, and when I began to pay attention I managed a few steps of creditable execution and then fell' (14). In keeping with Lady McCann's expectation of a logical cause for any departure from normative behavior, the Expelled offers an explanation for this unique characteristic that stems from early childhood experiences. His awareness of social expectations are also noted in his attempts to follow the law. The policeman's words to him are demonstrative of the story's thematization of the difficulty of maintaining one's position within the normalizing strictures of biopolitics. As he says: "if you can't bloody well get about like everyone else ... you better stay at home" (16).

14 Ali K. Yetisen defines "biohacking" as "a do-it-yourself citizen science merging body modification with technology" (744). Yetisen explains that one of the motivations for this new trend is the promotion of privacy rights against state access to personal biomedical data.

\section{Works Cited}

Althusser, Louis. Lenin and Philosophy and Other Essays. Trans. Ben Brewster. New York: Monthly Review Press, 2001.

Attridge, Derek. Peculiar Language: Literature as Difference from the Renaissance to James Joyce. London: Routledge, 2004.

Beckett, Samuel. "From an Abandoned Work". The Complete Short Prose, 1929-1989. Ed. S.E. Gontarski. New York: Grove Press, 1995. 155-164.

. "Le Concentrisme". Disjecta: Miscellaneous Writings and a Dramatic Fragment. Ed. Ruby Cohn. New York: Grove Press, 1984. 35-42.

. "The Expelled". Stories \& Texts for Nothing. Ed. Mark Nixon. New York: Grove Press, 1967. 7-27.

. Proust. New York: Grove Press, 1978.

Three Novels. New York: Grove Press, 1958.

Watt. New York: Calder, 1972.

Bourdieu, Pierre. Outline of a Theory of Practice. Trans. Richard Nice. Cambridge: Cambridge University Press, 1977.

Cohn, Ruby. A Beckett Canon. Ann Arbor: The University of Michigan Press, 2005.

Connor, Steven. "Shifting Ground". 3 August 2019. http://www.stevenconnor.com/beckettnauman/

Coole, Diana and Frost, Samantha. New Materialsms: Ontology, Agency, and Politics. Duke University Press, 2010.

Crary, Jonathan. Suspensions of Perception: Attention, Spectacle, and Modern Culture. Cambridge: MIT Press, 2001. 
Lyotard, Jean-François. Driftworks Trans. Roger McKeon. New York: Semiotext(e), 1984.

Malabou, Catherine. "One Life Only: Biological Resistance, Political Resistance". Critical Inquiry 42.3 (2016): 429-38.

Maude, Ulrika. "Beckett and the Laws of Habit." Modernism/Modernity 18.4 (2012): 813821.

- "“A Stirring Beyond Coming and Going': Beckett and Tourette's." Journal of Beckett Studies, 17:1-2 (2008): 153-168.

Mitchell David T. and Snyder Sharon L. The Biopolitics of Disability: Neoliberalism, Ablenationalism and Peripheral Embodiment. Ann Arbor: University of Michigan Press, 2015.

Nixon, Mark. "Preface". Texts for Nothing and Other Shorter Prose, 1950-1976. Ed. Mark Nixon. London: Faber and Faber, 2010.

Nordau, Max. Degeneration. London: William Heinemann, 1898.

North, Paul. The Problem of Distraction. Stanford: Stanford University Press, 2012.

Phillips, Natalie M. Distraction: Problems of Attention in Eighteenth-Century Literature. Baltimore: Johns Hopkins University Press, 2016.

Salisbury, Laura. Samuel Beckett: Laughing Matters, Comic Timing. Edinburgh: Edinburgh University Press, 2015.

Simondon, Gilbert. "The Genesis of the Individual". Trans. Mark Cohen and Sanford Kwinter. Incorporations. Eds. Jonathan Crary and Sanford Kwinter. New York: Zone, 1992. 297-319.

Van Hulle, Dirk. "The Extended Mind And Multiple Drafts: Beckett's Models of the Mind and the Postcognitivist Paradigm". Early Modern Beckett: Beckett Between. Eds. Angela B. Moorjani, Danièle de Ruyter, Dúnlaith Bird and Sjef Houppermans. Amsterdam: Brill Academic Publishers, 2012. 277-289.

Yetisen, Ali K. "Biohacking". Trends in Biotechnology 36.8 (2018): 744747. ProQuest. Web. 4 Aug. 2019.

Received: 7 June 2019

Revised version accepted: 14 September 2019

Yael Levin is a senior lecturer at the Hebrew University English Department and Vice President of the Joseph Conrad Society of America. She is author of Tracing the Aesthetic Principle in Conrad's Novels (Palgrave Macmillan, 2008) and the forthcoming Joseph Conrad: Slow Modernism (Oxford University Press, 2020). Her work on disability, modernism, postmodernism, narratology and the subject has appeared in a number of journals including Journal of Modern Literature, Journal of Beckett Studies, Partial Answers and Twentieth-Century Literature.

yael.levin@mail.huji.ac.il 